\title{
Root growth of soybean cultivars under different water availability conditions
}

\section{Crescimento radicular de cultivares de soja em campo em diferentes disponibilidades hídricas}

\author{
Julio Cezar Franchini ${ }^{1}$; Alvadi Antonio Balbinot Junior ${ }^{1 *}$; \\ Henrique Debiasi ${ }^{1}$; Alexandre Lima Nepomuceno ${ }^{1}$
}

\begin{abstract}
Vigorous growth of soybean root system is a desired trait in breeding programs. However, few studies have evaluated this feature under field conditions. The aim of this research was to evaluate root growth of eight soybean cultivars under different water availability conditions. The experiment was carried out in Londrina, Paraná state, Brazil, during two growing seasons - with and without water deficit during the vegetative period. Soybean roots were sampled at flowering and assessed for dry matter yield, area and length at $0-0.25 ; 0.25-0.50 ; 0.50-0.75$ and $0.75-1.00 \mathrm{~m}$ depth ranges. On average, root length and area of the cultivars Embrapa 48 and BRS 284 under water deficit were $66 \%$ and $40 \%$ larger than the others at $0.25-0.50$ and $0.50-0.75 \mathrm{~m}$ layers, respectively. Under suitable water supply, BRS 282 showed the highest root length and area. Apart from the cultivars Embrapa 48, BRS 284, and BRS 255RR, soybean root growth was mostly lower under water deficit throughout the vegetative stage, which might been due to a higher soil resistance to root penetration, resulting from low soil water content. Drought increased the proportion of soybean roots at subsoil layers, mainly for Embrapa 48 and BRS 284. The cultivars Embrapa 48 and BRS 284 are promising to be used in breeding programs targeting superior root growth in subsoil layers.
\end{abstract}

Key words: Glycine max L. Root area. Root length. Root mass.

\section{Resumo}

O crescimento vigoroso do sistema radicular da soja é uma característica almejada nos programas de melhoramento genético. No entanto, há poucos trabalhos na literatura que avaliaram essa característica em condição de campo. O objetivo dessa pesquisa foi avaliar o crescimento de raízes de oito cultivares de soja em diferentes situações de disponibilidade hídrica. O experimento foi conduzido em Londrina, $\mathrm{PR}$, em duas safras, uma com déficit hídrico no período vegetativo e outra sem déficit. As raízes da soja foram amostradas no florescimento e avaliadas quanto à massa seca, área e comprimento, nas camadas de $0-0,25 ; 0,25-0,50 ; 0,50-0,75$; e $0,75-1,00 \mathrm{~m}$. Na safra com déficit hídrico, o comprimento e área radicular das cultivares Embrapa 48 e BRS 284 foram, em média, 66\% e 40\% maiores do que as demais cultivares nas camadas de 0,25-0,50 e 0,50-0,75 m, respectivamente. Com adequada disponibilidade hídrica, a cultivar BRS 282 apresentou o maior comprimento e área radicular. Excetuando-se as cultivares Embrapa 48, BRS 284 e BRS 255RR, o crescimento radicular foi geralmente menor na safra com ocorrência de seca no estádio vegetativo, provavelmente em razão da maior resistência do solo à penetração das raízes. A seca aumentou a proporção de raízes em camadas mais profundas, principalmente na Embrapa 48 e BRS 284. As cultivares Embrapa 48 e BRS 284 são promissoras para a obtenção de linhagens com maior crescimento radicular em camadas subsuperficiais.

Palavras-chave: Glycine max L. Área de raízes. Comprimento de raízes. Massa de raízes.

\footnotetext{
${ }^{1}$ Pesquisadores, Empresa Brasileira de Pesquisa Agropecuária, EMBRAPA Soja, Londrina, PR, Brasil. E-mail: julio.franchini@ embrapa.br; alvadi.balbinot@embrapa.br; henrique.debiasi@embrapa.br; alexandre.nepomuceno@embrapa.br

* Author for correspondence
} 


\section{Introduction}

In Brazil, nearly 33.2 million ha were grown with soybeans in the $2015 / 2016$ growing season, reaching an average yield of $3 \mathrm{t} \mathrm{ha}^{-1}$ (CONAB, 2016). In several Brazilian regions, crop yield and stability are low, mainly because of drought and nutrient scarcity (STOLF et al., 2009). Irrigated soybean has little expression in Brazil, since farming areas are far away from water sources, as well as the high installation costs and energy consumption. Moreover, soybean farming in Brazil has spread widely, mainly over areas of sandy soils and high air temperatures, in which the risk of yield losses due to water and nutrient deficits are higher.

The key farming practices to reduce yield losses induced by droughts are based on no-tillage system (FRANCHINI et al., 2012), crop rotation (CALEGARI et al., 2006), proper sowing time with low probability of water shortfall at critical stages, and use of drought-tolerant cultivars (HUDAK; PATTERSON, 1996). Various morphophysiological characteristics affect soybean tolerance to drought and nutrients shortage, either increasing water uptake or reducing water loss to the atmosphere. Plants have several adaptation mechanisms to withstand water stress such as increasing translocation of photoassimilates to roots and extending roots into deeper soil layers (BENJAMIN; NIELSEN, 2006; DARDANELLII et al., 1997). Among them, plant ability to redefine root system distribution throughout the soil profile has been considered a crucial tolerance mechanism, largely determined by plant species (BENJAMIN; NIELSEN, 2006) and cultivars (SPONCHIADO et al., 1989). Nevertheless, information on root growth of soybean cultivars under field conditions is scarce, most likely because of the complexity of evaluation (PANTALONE et al., 1996). Identifying cultivars with high root growth at subsurface layers consists of a valuable information, as it indicates suitable cultivars for plant breeding program.

Several studies have shown drought effects on soybean root growth, but findings are adversarial
(BENJAMIN; NIELSEN, 2006; MERRILL et al., 2002). Root growth response to water stress is associated to various factors such as cultivar (HUDAK; PATTERSON, 1996), deficit timing in relation to soybean growth stage (HOOGENBOOM et al., 1987), and soil physical (BEUTLER; CENTURION, 2004; GREACEN; OH， 1972; RICHART et al., 2005), chemical (SPONCHIADO et al., 1989) or biological (BENGOUGH et al., 2011) limitations to root growth. In this context, it is said that soil mechanical resistance to root growth varies directly with the soil bulk density, and inversely with the soil water content (KLEIN et al., 2006; MORAES et al., 2014; VAZ et al., 2011). Thus, even if there is no soil compaction root growth can be impaired whether soil water content is low enough to render soil mechanical resistance limiting.

We hypothesized that root growth and distribution throughout the soil profile varies among soybean cultivars, especially in growing seasons with water deficits during the vegetative stage. Therefore, our study aimed to evaluate the root growth of eight soybean cultivars in four soil depth ranges, in two growing seasons under different water availabilities during the vegetative stage.

\section{Material and Methods}

The field experiment was conducted during two growing seasons in Londrina (23ำ $11^{\prime} \mathrm{S}$; $51^{\circ} 11^{\prime} \mathrm{W}$; and $620 \mathrm{~m}$ above sea level), Paraná State, southern Brazil. According to Köppen's classification, local climate is humid subtropical $(C f a)$, with mean annual temperature of $21^{\circ} \mathrm{C}$. Mean maximum and minimum temperatures are $28.5^{\circ} \mathrm{C}$ and $13.3^{\circ} \mathrm{C}$ in February and in July, respectively. Mean annual rainfall is 1,651 $\mathrm{mm}$, with an average of $217 \mathrm{~mm}$ in January (most humid), and $60 \mathrm{~mm}$ in August (driest). The soil is classified as an Oxisol (Dystroferric Red Latosol by the Brazilian Soil Classification System; and Rhodic Eutrudox by the USDA Soil Taxonomy), with 710

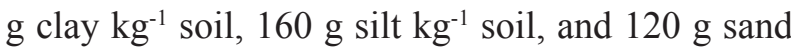


$\mathrm{kg}^{-1}$ soil, within 0.0-0.2 m depth. Analysis of a few soil chemical properties at 0.0-0.2 $\mathrm{m}$ layer prior to experiment installation were: organic carbon - 18.9 $\mathrm{g} \mathrm{dm}^{-3} ; \mathrm{pH}$ in water $-5.8 ; \mathrm{K}-0.44 \mathrm{cmol}_{\mathrm{c}} \mathrm{dm}^{-3} ; \mathrm{P}$ (Mehlich 1) - $11.9 \mathrm{mg} \mathrm{dm}^{-3} ; \mathrm{Ca}-8.01 \mathrm{cmol}_{\mathrm{c}} \mathrm{dm}^{-3}$ and $\mathrm{Mg}-1.73 \mathrm{cmol}_{\mathrm{c}} \mathrm{dm}^{-3}$.

The area has been managed under no-tillage with soybean in summer and black oat (Avena strigosa Schreb.) in winter for ten years; both crops received the same management and inputs. The experiment was laid out in a completely randomized block design, with four replications, and placed on the same area in both growing seasons. Treatments consisted of eight soybean cultivars (Table 1). The size of each plot was 4 x $5 \mathrm{~m}\left(20 \mathrm{~m}^{2}\right)$. Prior to soybean sowing, black oat was desiccated using glyphosate (720 g a.i. ha $\left.{ }^{-1}\right)$ mixed with mineral oil $\left(0.5 \mathrm{~L} \mathrm{ha}^{-1}\right)$. Soybean sowing was carried out in November for both growing seasons, using row spacing of $0.45 \mathrm{~m}$, and 250,000 plants $\mathrm{ha}^{-1}$. Soybeans were fertilized with $45 \mathrm{~kg} \mathrm{ha}^{-1}$ of phosphorus and $45 \mathrm{~kg} \mathrm{ha}^{-1}$ of potassium, applied $0.05 \mathrm{~m}$ below and alongside the seeds simultaneously with the sowing. Soybean seeds were inoculated with Bradyrhizobium elkanii and B. japonicum. After sowing, crop management and control of weeds, pests and diseases were the same as for all plots and strictly following technical recommendations for soybean production in the region.

Table 1. Soybean cultivars used in the experiments.

\begin{tabular}{ccc}
\hline Cultivars & Maturity group & Growth type \\
\hline BR 16 & 6.7 & Determinate \\
Embrapa 48 & 6.8 & Determinate \\
BRS 184 & 6.7 & Determinate \\
BRS 232 25 RR & 6.9 & Determinate \\
BRS 255 & Determinate \\
BRS 282 & 6.7 & Determinate \\
BRS 283 & 6.9 & Indeterminate \\
BRS 284 & 6.5 & Indeterminate \\
\hline
\end{tabular}

Source: Embrapa Soja.

Sequential water balance (Figure 1) was calculated according to Thornthwaite and Mather (1955), using ten-day temperature and rainfall gathered from October to March of both growing seasons, at a permanent weather station located at the experimental site. Plant-available water capacity in soil (PAWC) was estimated as $75 \mathrm{~mm}$, considering an effective root depth of $0.5 \mathrm{~m}$, and an available water content of $0.15 \mathrm{~m}^{3} \mathrm{~m}^{-3}$, corresponding to the difference between the volumetric water content $(\theta)$ at field capacity $(\mathrm{FC})$, at a matric potential $\left(\Psi_{\mathrm{m}}\right)$ of $-10 \mathrm{kPa}$, and a permanent wilting point (PWP $-\Psi_{\mathrm{m}}$ ) of $-1500 \mathrm{kPa}$, both determined using soil samples collected at the site. Estimation of potential evapotranspiration was made by the Thornthwaite (1948) method.

In both growing seasons, soybean root systems were evaluated at full bloom stage - R2 (FEHR et al., 1971). A $0.9 \mathrm{~m}$ wide and $1.0 \mathrm{~m}$ deep trench was opened perpendicularly to two soybean rows, per plot. Roots were evaluated following a method adapted from Crestana et al. (1994), assessing their length and area within subareas of $0.225 \mathrm{~m}$ wide x $0.250 \mathrm{~m}$ deep. For contrast, roots were painted white. Pictures of the subareas were taken using a digital camera, and then segmented using threshold technique. Next, images were analyzed and root length and area were estimated using Delta-T Scan software (Delta-T Devices Lta). 
Figure 1. Sequential 10-day water balance from October to March under water deficit (A) and without water deficit (B) growing seasons.
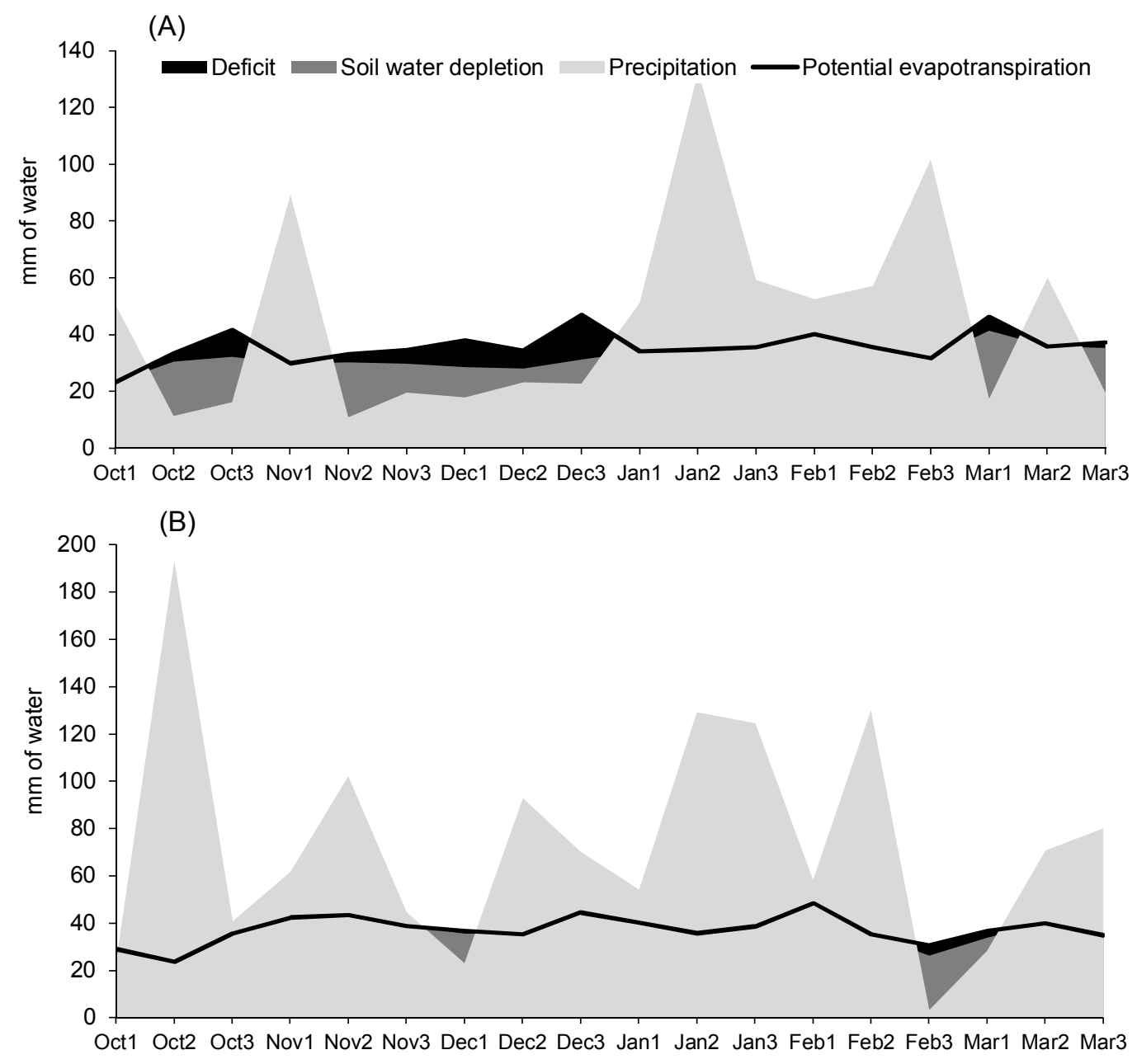

Source: Embrapa Soja.

After digital imaging, the soil blocks (subareas) were sliced into $0.05-\mathrm{m}$ sections with a trowel; the soil was packed into plastic bags and taken to the laboratory for root dry mass determination. There, soil was carefully washed in a water container, and the roots were separated with a 150-mesh sieve. Hereupon, roots were oven-dried at $\pm 50^{\circ} \mathrm{C}$ for 72 $\mathrm{h}$, and the root dry mass was determinate.

After testing variance homogeneity, normality, independence of residuals, and model nonadditivity, ANOVA was applied for each growing season singly. A combined statistical analysis was also performed by taking growing season as experimental factor. When ANOVA resulted in a significant $P$ value $(P \leq 0.05)$, the Scott-Knott test was used for multiple comparisons among cultivars.

\section{Results and Discussion}

The interaction between soybean cultivars and growing seasons was significant for all variables. During the drought season, root dry mass was significantly influenced by cultivars, but the effects depended on the soil layer. The BR 16 cultivar showed the highest root dry mass in the upper soil layer (0.0- $0.25 \mathrm{~m})$, being about twice as high 
compared to the other cultivars (Table 2). However, the greatest root dry weight was observed for Embrapa 48 and BR 16 at 0.25-0.50-m layer, and for BRS 232, BRS 184 and Embrapa 48 at 0.50 $0.75-\mathrm{m}$ depth. The differences among cultivars grown under water deficit were not significant at 0.75-1.00-m depth. Conversely, root dry mass had no difference among cultivars at all soil layers when grown without water deficit.

Table 2. Root dry mass, root area, and root length of eight soybean cultivars evaluated during the R2 stage at 0.0-0.25, $0.25-0.50,0.50-0.75$ and $0.75-1.00 \mathrm{~m}$ depth with and without water deficit during the vegetative stage.

\begin{tabular}{|c|c|c|c|c|c|c|}
\hline \multirow[b]{2}{*}{$\begin{array}{l}\text { Soybean } \\
\text { cultivars }\end{array}$} & \multicolumn{2}{|c|}{ Root dry mass } & \multicolumn{2}{|c|}{ Root area } & \multicolumn{2}{|c|}{ Root length } \\
\hline & $\begin{array}{l}\text { With water } \\
\text { deficit }\end{array}$ & $\begin{array}{l}\text { Without water } \\
\text { deficit }\end{array}$ & $\begin{array}{l}\text { With water } \\
\text { deficit }\end{array}$ & $\begin{array}{l}\text { Without water } \\
\text { deficit }\end{array}$ & $\begin{array}{l}\text { With water } \\
\text { deficit }\end{array}$ & $\begin{array}{l}\text { Without wa- } \\
\text { ter deficit }\end{array}$ \\
\hline & \multicolumn{2}{|c|}{-------- Mg ha ${ }^{-1}$-------- } & \multicolumn{2}{|c|}{$\begin{array}{c}-----\mathrm{mm}^{2} \mathrm{~cm}^{-3}------- \\
0.00-0.25 \mathrm{~m}\end{array}$} & \multicolumn{2}{|c|}{-------- $\mathrm{cm} \mathrm{cm}^{-3}$-------- } \\
\hline BR 16 & $1.86 \mathrm{a} A$ & $1.26 \mathrm{a} \mathrm{B}$ & $2.33 \mathrm{a} \mathrm{B}$ & $3.77 \mathrm{~b} \mathrm{~A}$ & 0.50 a B & $0.76 \mathrm{~b} \mathrm{~A}$ \\
\hline Embrapa 48 & $0.92 \mathrm{~b} \mathrm{~A}$ & $1.09 \mathrm{a} \mathrm{A}$ & $3.06 \mathrm{a} \mathrm{A}$ & $3.39 \mathrm{~b} \mathrm{~A}$ & 0.58 a A & $0.69 \mathrm{~b} \mathrm{~A}$ \\
\hline BRS 184 & $0.86 \mathrm{~b} \mathrm{~A}$ & 0.89 a $\mathrm{A}$ & 2.56 a B & $6.73 \mathrm{a} A$ & 0.64 a B & $0.95 \mathrm{a} \mathrm{A}$ \\
\hline BRS 232 & $0.88 \mathrm{~b} \mathrm{~A}$ & 0.96 a A & $2.20 \mathrm{a} \mathrm{B}$ & $5.60 \mathrm{a} A$ & 0.52 a B & 0.87 a A \\
\hline BRS 255 & $1.03 \mathrm{~b} \mathrm{~A}$ & 0.84 a A & $1.94 \mathrm{a} A$ & $2.13 \mathrm{c} \mathrm{A}$ & 0.46 a A & $0.41 \mathrm{c} \mathrm{A}$ \\
\hline BRS 282 & $0.52 \mathrm{~b} \mathrm{~B}$ & $1.12 \mathrm{a} \mathrm{A}$ & $2.47 \mathrm{a} B$ & $6.27 \mathrm{a} \mathrm{A}$ & 0.58 a B & $1.05 \mathrm{a} \mathrm{A}$ \\
\hline BRS 283 & $0.57 \mathrm{~b} \mathrm{~B}$ & $1.48 \mathrm{a} \mathrm{A}$ & $1.82 \mathrm{a} B$ & $3.41 \mathrm{~b} \mathrm{~A}$ & 0.47 a A & $0.54 \mathrm{c} \mathrm{A}$ \\
\hline BRS 284 & $0.96 \mathrm{~b} \mathrm{~A}$ & $1.12 \mathrm{a} \mathrm{A}$ & 1.89 a B & $3.44 \mathrm{~b} \mathrm{~A}$ & 0.48 a B & $0.69 \mathrm{~b} \mathrm{~A}$ \\
\hline $\mathrm{CV}(\%)$ & \multicolumn{2}{|c|}{36.6} & \multicolumn{2}{|c|}{20.6} & \multicolumn{2}{|c|}{17.0} \\
\hline BR 16 & $0.25 \mathrm{a} \mathrm{A}$ & 0.17 a B & $0.76 \mathrm{~b} \mathrm{~A}$ & $1.12 \mathrm{c} \mathrm{A}$ & $0.16 \mathrm{~b} \mathrm{~A}$ & $0.22 \mathrm{c} \mathrm{A}$ \\
\hline Embrapa 48 & $0.25 \mathrm{a} \mathrm{A}$ & 0.17 a B & $1.52 \mathrm{a} \mathrm{A}$ & 0.74 c B & $0.27 \mathrm{a} \mathrm{A}$ & 0.16 c B \\
\hline BRS 184 & $0.16 \mathrm{~b} \mathrm{~A}$ & $0.15 \mathrm{a} \mathrm{A}$ & $0.82 \mathrm{~b} \mathrm{~B}$ & $1.61 \mathrm{~b} \mathrm{~A}$ & $0.21 \mathrm{~b} \mathrm{~A}$ & $0.29 \mathrm{~b} \mathrm{~A}$ \\
\hline BRS 232 & $0.10 \mathrm{~b} \mathrm{~A}$ & $0.15 \mathrm{a} \mathrm{A}$ & $0.76 \mathrm{~b} \mathrm{~B}$ & $1.79 \mathrm{~b} \mathrm{~A}$ & $0.19 \mathrm{~b} \mathrm{~B}$ & $0.29 \mathrm{~b} \mathrm{~A}$ \\
\hline BRS 255 & $0.13 \mathrm{~b} \mathrm{~A}$ & 0.19 a A & $0.85 \mathrm{~b} \mathrm{~A}$ & 0.78 с A & $0.21 \mathrm{~b} \mathrm{~A}$ & $0.15 \mathrm{c} \mathrm{A}$ \\
\hline BRS 282 & $0.08 \mathrm{~b} \mathrm{~B}$ & $0.17 \mathrm{a} \mathrm{A}$ & $0.77 \mathrm{~b} \mathrm{~B}$ & $2.20 \mathrm{a} A$ & $0.20 \mathrm{~b} \mathrm{~B}$ & 0.38 a A \\
\hline BRS 283 & $0.13 \mathrm{~b} \mathrm{~A}$ & $0.13 \mathrm{a} \mathrm{A}$ & $0.66 \mathrm{~b} \mathrm{~A}$ & 0.93 c A & $0.16 \mathrm{~b} \mathrm{~A}$ & $0.16 \mathrm{c} \mathrm{A}$ \\
\hline BRS 284 & $0.15 \mathrm{~b} \mathrm{~A}$ & 0.18 a A & $1.22 \mathrm{a} \mathrm{A}$ & $0.91 \mathrm{c} \mathrm{A}$ & $0.27 \mathrm{a} \mathrm{A}$ & $0.18 \mathrm{c} \mathrm{B}$ \\
\hline $\mathrm{CV}(\%)$ & \multicolumn{2}{|c|}{33.6} & \multicolumn{2}{|c|}{30.9} & \multicolumn{2}{|c|}{25.6} \\
\hline BR 16 & $0.07 \mathrm{~b} \mathrm{~A}$ & $0.12 \mathrm{a} A$ & $0.65 \mathrm{~b} \mathrm{~B}$ & $1.01 \mathrm{c} \mathrm{A}$ & $0.15 \mathrm{~b} \mathrm{~A}$ & $0.20 \mathrm{~b} \mathrm{~A}$ \\
\hline Embrapa 48 & $0.13 \mathrm{a} \mathrm{A}$ & $0.13 \mathrm{a} \mathrm{A}$ & $1.17 \mathrm{a} \mathrm{A}$ & $0.95 \mathrm{c} \mathrm{A}$ & $0.21 \mathrm{a} \mathrm{A}$ & $0.21 \mathrm{~b} \mathrm{~A}$ \\
\hline BRS 184 & $0.12 \mathrm{a} A$ & $0.11 \mathrm{a} \mathrm{A}$ & $0.60 \mathrm{~b} \mathrm{~B}$ & 0.98 с A & $0.16 \mathrm{~b} \mathrm{~A}$ & $0.18 \mathrm{~b} \mathrm{~A}$ \\
\hline BRS 232 & 0.18 a A & 0.09 a B & $0.84 \mathrm{~b} \mathrm{~B}$ & $1.23 \mathrm{~b} \mathrm{~A}$ & $0.20 \mathrm{~b} \mathrm{~A}$ & $0.22 \mathrm{~b} \mathrm{~A}$ \\
\hline BRS 255 & $0.07 \mathrm{~b} \mathrm{~A}$ & $0.11 \mathrm{a} \mathrm{A}$ & $0.77 \mathrm{~b} \mathrm{~A}$ & 0.96 с A & $0.19 \mathrm{~b} \mathrm{~A}$ & $0.19 \mathrm{~b} \mathrm{~A}$ \\
\hline BRS 282 & $0.04 \mathrm{~b} \mathrm{~B}$ & $0.13 \mathrm{a} \mathrm{A}$ & $0.74 \mathrm{~b} \mathrm{~B}$ & $1.52 \mathrm{a} A$ & $0.19 \mathrm{~b} \mathrm{~B}$ & $0.29 \mathrm{a} \mathrm{A}$ \\
\hline BRS 283 & $0.06 \mathrm{~b} \mathrm{~A}$ & $0.10 \mathrm{a} A$ & $0.58 \mathrm{~b} \mathrm{~B}$ & 0.96 с A & $0.14 \mathrm{~b} \mathrm{~A}$ & $0.17 \mathrm{~b} \mathrm{~A}$ \\
\hline BRS 284 & $0.10 \mathrm{~b} \mathrm{~A}$ & 0.09 a A & 0.99 a A & 0.78 с A & 0.26 a A & $0.17 \mathrm{~b} \mathrm{~B}$ \\
\hline $\mathrm{CV}(\%)$ & \multicolumn{2}{|c|}{46.5} & \multicolumn{2}{|c|}{21.2} & \multicolumn{2}{|c|}{19.7} \\
\hline BR 16 & 0.03 a B & $0.07 \mathrm{a} \mathrm{A}$ & $0.58 \mathrm{a} \mathrm{A}$ & $0.81 \mathrm{a} \mathrm{A}$ & $0.13 \mathrm{~b} \mathrm{~A}$ & $0.16 \mathrm{a} \mathrm{A}$ \\
\hline Embrapa 48 & 0.08 a A & $0.05 \mathrm{a} \mathrm{A}$ & $0.47 \mathrm{a} \mathrm{A}$ & $0.59 \mathrm{~b} \mathrm{~A}$ & $0.10 \mathrm{~b} \mathrm{~A}$ & $0.13 \mathrm{a} \mathrm{A}$ \\
\hline BRS 184 & $0.07 \mathrm{a} \mathrm{A}$ & $0.04 \mathrm{a} \mathrm{A}$ & 0.46 a B & $0.91 \mathrm{a} A$ & $0.12 \mathrm{~b} \mathrm{~A}$ & $0.14 \mathrm{a} \mathrm{A}$ \\
\hline BRS 232 & 0.08 a A & $0.05 \mathrm{a} \mathrm{A}$ & 0.60 a $\mathrm{A}$ & 0.80 a A & $0.17 \mathrm{a} \mathrm{A}$ & 0.14 a A \\
\hline BRS 255 & $0.05 \mathrm{a} \mathrm{A}$ & $0.05 \mathrm{a} \mathrm{A}$ & $0.50 \mathrm{a} A$ & $0.29 \mathrm{~b} \mathrm{~A}$ & $0.13 \mathrm{~b} \mathrm{~A}$ & $0.06 \mathrm{~b} \mathrm{~B}$ \\
\hline BRS 282 & $0.07 \mathrm{a} \mathrm{A}$ & 0.06 a A & 0.62 a B & 0.94 a A & 0.16 a A & 0.16 a $\mathrm{A}$ \\
\hline BRS 283 & $0.05 \mathrm{a} \mathrm{A}$ & $0.05 \mathrm{a} \mathrm{A}$ & 0.32 a A & $0.51 \mathrm{~b} \mathrm{~A}$ & $0.09 \mathrm{~b} \mathrm{~A}$ & $0.10 \mathrm{~b} \mathrm{~A}$ \\
\hline BRS 284 & $0.07 \mathrm{a} \mathrm{A}$ & 0.06 a A & 0.68 a A & $0.37 \mathrm{~b} \mathrm{~B}$ & 0.19 a $\mathrm{A}$ & $0.08 \mathrm{~b} \mathrm{~B}$ \\
\hline $\mathrm{CV}(\%)$ & \multicolumn{2}{|c|}{45.4} & \multicolumn{2}{|c|}{28.5} & \multicolumn{2}{|c|}{32.2} \\
\hline
\end{tabular}

For each variable, means followed by the same letters, lowercase in the columns and uppercase in the rows, do not differ by ScottKnott and $\mathrm{F}$ tests, respectively $(\mathrm{P} \leq 0.05)$. 
Under water deficit, root spread area was similar among all cultivars at both 0.0-0.25 and 0.75-1.00m layers, however, Embrapa 48 and BRS 284 reached values, on average, $78 \%$ and $55 \%$ wider than the others at $0.25-0.50$ and $0.50-0.75-\mathrm{m}$ layers, respectively (Table 2). In absence of water deficit, BRS 184, BRS 232, and BRS 282 showed increasing root areas at 0.0-0.25 and 0.75-1.00-m depth ranges. In the intermediate layers, BRS 282 stood out with the largest root area. Root length variations among cultivars were similar to those of root area (Table 2). In the uppermost soil layer (0.0-0.25 m), BRS 184, BRS 232, and BRS 282 exhibited the longest roots during the most humid season, yet under hydric shortfall no variation was seen among cultivars. Under water deficit, root lengths were, on average, approximately $40 \%$ longer for Embrapa 48 and BRS 284, at 0.25-0.50 $\mathrm{m}$ and 0.50-0.75-m layers, while BRS 284, BRS 232 and BRS 282 were lengthy at 0.75-1.00 m layer. Additionally, BRS 282 achieved the most significant root length at intermediate layers throughout the wetter growing season.

In our study, the root dry mass, length and area varied widely among cultivars, with and without water deficit at vegetative growth stage. Although the largest root dry mass, area and length were observed at $0.0-0.25 \mathrm{~m}$ depth, the greatest root growth changes among cultivars occurred at the layers of 0.25-0.50 and 0.50-0.70 m. Dardanelli et al. (1997) also found significant differences in root growth comparing three soybean cultivars, which was stated as a cultivar-specific ability of uptaking water and nutrients from deeper soil layers.

Root growth response of soybeans to the distinct water availabilities of each growing season was strongly influenced by the cultivar, as previously demonstrated by Hudak and Patterson (1996). Moreover, the variables root area and length were more sensitive than dry weight to predict the effects of growing season on soybean root growth. According to Table 2, BRS 282 exhibited the highest root growth under suitable hydric conditions; nonetheless, it had the major reduction in dry mass, area, and root length when under drought at depth ranges of $0.0-0.25,0-25-0.50$, and $0.50-0.75 \mathrm{~m}$, displaying a highly drought-sensitive root system. Considering all depths together, BRS 282 root dry mass, area and length were nearly 215,240 , and $170 \%$ lower under drought than when under proper water supply, respectively. Likewise, the root area, length and dry mass of BRS 184, BRS 232, and BRS 283 were overall similar in the drier growing season or lower in the season with proper water availability, for all layers evaluated. Conversely, when submitted to drought, Embrapa 48 and BRS 284 maintained or increased root area, length and dry mass within a depth range from 0.25 to $1.00 \mathrm{~m}$ compared to when under adequate water availability, indicating thus little influence from water deficit on root growth for these cultivars. Interestingly, BRS 255RR showed one of the least drought-sensitive root system, once root area, length and dry mass were not significantly affected by the season in all layers studied. Nevertheless, this result cannot be considered as a drought-tolerance indicator for BRS 255RR, since this cultivar showed low root area and length in both growing seasons.

The concept that soybean root growth is increased by drought has been widely spread in Brazil. In our study, excepting the cultivars Embrapa 48, BRS 284, and BRS 255RR, soybean root growth was generally lower under water deficit. In the literature, the results regarding root growth response to drought have been contradictory. Hoogenboom et al. (1987) and Merrill et al. (2002) found increased soybean root growth under drought. By contrast, Benjamin and Nielsen (2006) observed increased soybean root area under adequate soil water availability. Root growth response to drought is determined by several factors such as water deficit intensity, water deficit timing regarding crop stage (HOOGENBOOM et al., 1987), soil restrictive conditions to root growth (BENGOUGH et al., 2011; BUSSCHER et al., 1997; GREACEN; OH, 1972; SPONCHIADO et al., 1989), and soybean genotype (HUDAK; PATTERSON, 1996). 
It is possible that the root systems of Embrapa 48 and BRS 284 might have particular morphophysiological traits which enhance root ability to break high soil penetration resistance (PR). Such traits could be higher turgor pressure at elongation zone; ability to seek for soil regions with lower mechanical resistance; sharper root tips; production of mucilage and other root deposits modifying soil mechanical properties and reducing frictional resistance between roots and soil; softer cell walls in the axial direction; and higher production of root hairs near tips for better root fixation, as discussed by Bengough et al. (2011). These differences among soybean cultivars concerning root abilities to explore compacted soil layers had been previously reported by Cardoso et al. (2006).

The effects of cultivar and growing season on the relative distribution of soybean roots in the soil profile varied according the variables considered. The highest proportion of root dry mass, 74.8\% under water deficit and $76.0 \%$ without water deficit, was concentrated in the uppermost soil layer (Table $3)$. The effects of growing seasons and cultivars were small; however, BR 16 and BRS 283 showed the highest proportion of root dry mass at 0.0-0.25 $m$ depth with and without water deficit, respectively. Benjamin and Nielsen (2006) found higher concentration of root dry mass in the uppermost soil layer, equivalent to over $90 \%$ at $0-0.23 \mathrm{~m}$ depth. The relative distribution of root length and area was influenced by cultivars and growing seasons. On the average across cultivars, the proportion of root length and area at the uppermost soil layer increased from approximately $50 \%$ in the drier growing season to about $60 \%$ under adequate water supply in vegetative stage. Accordingly, the proportion of root length and area at layers deeper than $0.25 \mathrm{~m}$ were higher under water deficit in relation to absence of drought, and the greatest increment was observed for the deepest layer $(0.75-1.00 \mathrm{~m})$. The reduction in the proportion of root length and area in the uppermost soil layer under water deficit occurred for all cultivars, but it was more evident in BRS 284, BRS 232, and Embrapa 48 (Table 3). For BRS 284 , the reduction in the proportion of root length and area at $0.0-0.25 \mathrm{~m}$ depth was counteracted by increasing at all deeper layers. Additionally, the proportion of root length and area at the deepest layer $(0.75-1.00 \mathrm{~m})$ for BRS 284 decreased from $14.2 \%$ and $15.8 \%$ under drought to $6.7 \%$ and $7.1 \%$ in adequate water availability in vegetative stage, respectively.

The plant ability to modify root distribution in the soil profile in response to water stress has been recognized as an important mechanism of drought tolerance (SPONCHIADO et al., 1989). Although root growth was usually higher in the growing season with adequate water availability, the proportion of roots at $0.25-1.00 \mathrm{~m}$ depth increased due to the water stress observed under drought, and this increase was more evident for BRS 284. The higher proportion of roots in deeper layers under water deficit can be explained by a higher reduction of the root growth at $0.0-0.25 \mathrm{~m}$ depth in this growing season, which can be attributed, among other factors, to the larger PR values in this layer as a result of higher water loss by evapotranspiration. In contrast, Benjamin and Nielsen (2006) concluded that the relative distribution of soybean roots with depth was not altered by the water deficit, suggesting that this characteristic is probably influenced by other factors, such as cultivar and soil properties. 
Table 3. Percentage of root dry mass, root area, and root length of eight soybean cultivars at $0.0-0.25,0.25-0.50,0.50-$ 0.75 and $0.75-1.00 \mathrm{~m}$ layers with and without water deficit during the vegetative stage.

\begin{tabular}{|c|c|c|c|c|c|c|}
\hline \multirow[b]{2}{*}{$\begin{array}{l}\text { Soybean cul- } \\
\text { tivars }\end{array}$} & \multicolumn{2}{|c|}{ Root dry mass } & \multicolumn{2}{|c|}{ Root area } & \multicolumn{2}{|c|}{ Root length } \\
\hline & $\begin{array}{c}\text { With water } \\
\text { deficit }\end{array}$ & $\begin{array}{c}\text { Without water } \\
\text { deficit }\end{array}$ & $\begin{array}{c}\text { With water } \\
\text { deficit }\end{array}$ & $\begin{array}{c}\text { Without water } \\
\text { deficit }\end{array}$ & $\begin{array}{c}\text { With water } \\
\text { deficit }\end{array}$ & $\begin{array}{c}\text { Without water } \\
\text { deficit }\end{array}$ \\
\hline & \multicolumn{6}{|c|}{$0.00-0.25 \mathrm{~m}$} \\
\hline BR 16 & 84.2 & 77.3 & 53.9 & 56.2 & 53.2 & 56.7 \\
\hline Embrapa 48 & 67.2 & 74.2 & 49.2 & 59.8 & 50.0 & 58.0 \\
\hline BRS 184 & 72.3 & 73.0 & 57.7 & 65.8 & 56.6 & 60.9 \\
\hline BRS 232 & 72.7 & 75.6 & 50.0 & 59.4 & 48.1 & 57.2 \\
\hline BRS 255 & 79.2 & 70.6 & 47.8 & 51.2 & 46.5 & 50.6 \\
\hline BRS 282 & 76.5 & 76.2 & 53.7 & 57.4 & 51.3 & 55.9 \\
\hline BRS 283 & 70.4 & 83.6 & 53.8 & 58.7 & 54.7 & 55.7 \\
\hline BRS 284 & 76.2 & 77.2 & 39.5 & 62.5 & 40.0 & 61.6 \\
\hline \multirow[t]{2}{*}{ Mean } & 74.8 & 75.9 & 50,7 & 58,9 & 50,1 & 57,1 \\
\hline & \multicolumn{6}{|c|}{$0.25-0.50 \mathrm{~m}$} \\
\hline BR 16 & 11.3 & 10.4 & 17.6 & 16.7 & 17.0 & 16.4 \\
\hline Embrapa 48 & 18.2 & 11.6 & 24.4 & 13.1 & 23.3 & 13.4 \\
\hline BRS 184 & 13.4 & 12.3 & 18.5 & 15.7 & 18.6 & 18.6 \\
\hline BRS 232 & 8.3 & 11.8 & 17.3 & 19.0 & 17.6 & 19.1 \\
\hline BRS 255 & 10.0 & 16.0 & 20.9 & 18.8 & 21.2 & 18.5 \\
\hline BRS 282 & 11.8 & 11.6 & 16.7 & 20.1 & 17.7 & 20.2 \\
\hline BRS 283 & 16.0 & 7.3 & 19.5 & 16.0 & 18.6 & 16.5 \\
\hline BRS 284 & 11.9 & 12.4 & 25.5 & 16.5 & 22.5 & 16.1 \\
\hline \multirow[t]{2}{*}{ Mean } & 12.6 & 11.7 & 20,1 & 17,0 & 19,6 & 17.4 \\
\hline & \multicolumn{6}{|c|}{$0.50-0.75 \mathrm{~m}$} \\
\hline BR 16 & 3.2 & 7.4 & 15.0 & 15.1 & 16.0 & 14.9 \\
\hline Embrapa 48 & 9.5 & 8.8 & 18.8 & 16.8 & 18.1 & 17.6 \\
\hline BRS 184 & 10.1 & 9.0 & 13.5 & 9.6 & 14.2 & 11.5 \\
\hline BRS 232 & 14.9 & 7.1 & 19.1 & 13.1 & 18.5 & 14.5 \\
\hline BRS 255 & 5.4 & 9.2 & 19.0 & 23.1 & 19.2 & 23.5 \\
\hline BRS 282 & 5.9 & 8.8 & 16.1 & 13.9 & 16.8 & 15.4 \\
\hline BRS 283 & 7.4 & 5.7 & 17.2 & 16.5 & 16.3 & 17.5 \\
\hline BRS 284 & 7.9 & 6.2 & 20.7 & 14.2 & 21.7 & 15.2 \\
\hline \multirow[t]{2}{*}{ Mean } & 8.1 & 7.8 & 17,4 & 15,3 & 17,6 & 16.3 \\
\hline & \multicolumn{6}{|c|}{$0.75-1.00 \mathrm{~m}$} \\
\hline BR 16 & 1.4 & 4.9 & 13.4 & 12.1 & 13.8 & 11.9 \\
\hline Embrapa 48 & 5.1 & 5.4 & 7.6 & 10.4 & 8.6 & 10.9 \\
\hline BRS 184 & 4.2 & 5.7 & 10.4 & 8.9 & 10.6 & 9.0 \\
\hline BRS 232 & 4.1 & 5.5 & 13.6 & 8.5 & 15.7 & 9.2 \\
\hline BRS 255 & 5.4 & 4.2 & 12.3 & 7.0 & 13.1 & 7.4 \\
\hline BRS 282 & 5.9 & 3.4 & 13.5 & 8.6 & 14.2 & 8.5 \\
\hline BRS 283 & 6.2 & 3.4 & 9.5 & 8.8 & 10.5 & 10.3 \\
\hline BRS 284 & 4.0 & 4.1 & 14.2 & 6.7 & 15.8 & 7.1 \\
\hline Mean & 4.5 & 4.6 & 11,8 & 8,9 & 12,8 & 9.3 \\
\hline
\end{tabular}

The percentage of root dry mass was higher than the percentage of root length or area at 0.0-0.25 $\mathrm{m}$ depth (Table 3), indicating thicker roots in the topsoil, as also observed Benjamin e Nielsen (2006). In contrast, the percentage of root area and length were higher than the percentage of root dry mass at 0.25-1.0 $\mathrm{m}$ depth. This result indicates thinner roots at deeper soil layers, leading to a greater root area for water and nutrient uptake by unit of photosynthates allocated during root formation. 


\section{Conclusions}

The Embrapa 48 and BRS 284 cultivars are promising for breeding programs to attain progenies with improved root growth at subsoil layers and under drought conditions.

Low water content in soil during a vegetative stage reduces root growth for most of the evaluated soybean cultivars.

Drought alters the relative distribution of soybean root system in the soil profile, increasing the proportion of roots at deeper layers.

\section{References}

BENGOUGH, A. G.; MCKENZIE, B. M.; HALLETT, P. D.; VALENTINE, T. A. Root elongation, water stress, and mechanical impedance: a review of limiting stresses and beneficial root tip traits. Journal of Experimental Botany, Lancaster, v. 62, n. 2, p. 59-68, 2011.

BENJAMIN, J. G.; NIELSEN, D. C. Water deficit effects on root distribution of soybean, field pea and chickpea. Field Crops Research, Amsterdam, v. 97, n. 2-3, p. 248253, 2006.

BEUTLER, A. N.; CENTURION, J. F. Compactação do solo no desenvolvimento radicular e na produtividade da soja. Pesquisa Agropecuária Brasileira, Brasília, v. 39, n. 6, p. 581-588, 2004.

BUSSCHER, W. J.; BAUER, P. J.; CAMP, C. R.; SOJKA, R. E. Correction of cone index for soil water content differences in a coastal plain soil. Soil \& Tillage Research, Amsterdam, v. 43, n. 2, p. 205-217, 1997.

CALEGARI, A.; CASTRO FILHO, C.; TAVARES FILHO, J.; RALISCH, R.; GUIMARÃES, M. F. Melhoria da agregação do solo através do sistema plantio direto. Semina: Ciências Agrárias, Londrina, v. 27, n. 2, p. $147-158,2006$.

CARDOSO, E. G.; ZOTARELLI, L.; PICCININ, J. L.; TORRES, E.; SARAIVA, O. F.; GUIMARÃES, M. F. Sistema radicular da soja em função da compactação do solo no sistema de plantio direto. Pesquisa Agropecuária Brasileira, Brasília, v. 41, n. 3, p. 493-501, 2006.

COMPANHIA NACIONAL DE ABASTECIMENTO - CONAB. Acompanhamento da safra brasileira grãos. Brasília: Conab, 2016. Available at: $<$ http:// www.conab.gov.br/OlalaCMS/uploads/arquivos/16 03 11 15_20_36_boletim_graos_marco_2016.pdf $>$. Accessed at: 15 mar. 2016.
CRESTANA, S.; GUIMARÃES, M. F.; JORGE, L. A. C.; RALISH, R.; TOZZI, C. L.; TORRE, A.; VAZ, C. M. P. Avaliação da distribuição de raízes no solo auxiliada por processamento de imagens digitais. Revista Brasileira de Ciência do Solo, Campinas, v.18, n. 3, p. 365-371, 1994.

DARDANELLI, J. L.; BOCHMEIER, O. A.; SERENO, R.; GIL, R. Rooting depth and soil water extraction patterns of different crops in a silty loam Haplustoll. Field Crops Research, Amsterdam, v. 54, n. 1, p. 29-38, 1997.

FEHR, W. R.; CAVINESS, C. E.; BURMOOD, D. T.; PENNINGTON, J. S. Stage of development descriptions for soybeans, Glycine $\max$ (L.) Merrill. Crop Science, Madison, v. 11, n. 6, p. 29-31, 1971.

FRANCHINI, J. C.; DEBIASI, H.; BALBINOT JUNIOR, A. A.; TONON, B. C.; FARIAS, J. R. B.; OLIVEIRA, M. C. N.; TORRES, E. Evolution of crop yields in different tillage and growing systems over two decades in Southern Brazil. Field Crops Research, Amsterdam, v. 137, n. 1, p. 178-185, 2012.

GREACEN, E. L.; OH, J. S. Physics of root growth. Nature, London, v. 235, n. 1, p. 24-25, 1972.

HOOGENBOOM, G.; HUCK, M. G.; PETERSON, C. M. Root growth rate of soybean as affected by drought stress. Agronomy Journal, Madison, v. 79, n. 4, p. 607614, 1987.

HUDAK, C. M.; PATTERSON, R. P. Root distribution and soil moisture depletion pattern of a drought-resistant soybean plant introduction. Agronomy Journal, Madison, v. 88 , n. 6 , p. $478-485,1996$.

KLEIN, V. A.; REICHERT, J. M.; REINERT, D. J. Água disponível em um Latossolo Vermelho argiloso e murcha fisiológica de culturas. Revista Brasileira de Engenharia Agrícola e Ambiental, Campina Grande, v. 10, n. 6, p. 646-650, 2006.

MERRILL, S. D.; TANAKA, D. L.; HANSON, J. D. Root length growth of eight crop species in Haplustoll soils. Soil Science Society of America Journal, Madison, v. 66, n. 3, p. 913-923, 2002.

MORAES, M. T.; DEBIASI, H.; CARLESSO, R.; FRANCHINI, J. C.; SILVA, V. R. Critical limits of soil penetration resistance in a rhodic Eutrudox. Revista Brasileira de Ciência do Solo, Viçosa, MG, v. 38, n. 1, p. 288-298, 2014

PANTALONE, V. R.; REBETZKE, G. J.; BURTON, J. W.; CARTER, T. E. Phenotypic evaluation of root traits in soybean and applicability to plant breeding. Crop Science, Madison, v. 36, n. 2, p. 456-459, 1996. 
RICHART, A.; TAVARES FILHO, J.; BRITO, O. R.; LLANILLO, R. F.; FERREIRA, R. Compactação do solo: causas e feitos. Semina: Ciências Agrárias, Londrina, v. 26, n. 3, p. 321-344, 2005.

SPONCHIADO, B. N.; WHITE, J. W.; CASTILLO, J. A.; JONES, P. G. Root growth of four common bean cultivars in relation to drought tolerance in environments with contrasting soil types. Experimental Agriculture, Cambridge, v. 25, n. 2, p. 249-257, 1989.

STOLF, R.; MEDRI, M. E.; PIMENTA, J. A.; BOEGER, M. R. T.; DIAS, J.; LEMOS, N. G.; OLIVEIRA, M. C. N.; BROGIN, R. L.; YAMANAKA, N.; NEUMAIER, N.; FARIAS, J. R. B.; NEPOMUCENO, A. L. Morphoanatomical and micromorphometrical evaluation in soybean genotypes during water stress. Brazilian Archives of Biology and Technology, Curitiba, v. 52, n. 6, p. 1321-1331, 2009.

THORNTHWAITE, C. W. An approach toward a rational classification of climate. Geographical Review, New York, v. 38, n. 1, p. 55-94, 1948.

THORNTHWAITE, C. W.; MATHER, J. R. The water balance. Centerton: Drexel Institute of Technology Laboratory of Climatology, 1955. 104 p. (Publications in Climatology, v. VIII, n. 1).

VAZ, C. M. P.; MANIERI, J. M.; MARIA, I. C.; TULLER, $\mathrm{M}$. Modeling and correction of soil penetration resistance for varying soil water content. Geoderma, Amsterdam, v. 166, n. 1, p. 92-101, 2011. 